\title{
PELATIHAN WIRAWISATA BAGI LULUSAN PAKET B KELAS BERJALAN DI KELURAHAN SETIAWARGI KECAMATAN TAMANSARI KOTA TASIKMALAYA
}

\author{
${ }^{1}$ Lulu Yuliani, ${ }^{2}$ Lilis Karwati, ${ }^{3}$ Wiwin Herwina \\ 1,2,3 Jurusan Pendidikan Luar Sekolah Fakultas Keguruan dan Ilmu Pendidikan Universitas Siliwangi \\ luluyuliani@unsil.ac.id
}

\begin{abstract}
ABSTRAK
Pendidikan nonformal merupakan jalur Pendidikan yang berfungsi sebagai penambah, pelengkap dan pengganti pendidikan Formal. Pendidikan nonformal sangat erat kaitannya dalam Pendidikan masyarakat. Pelatihan Wirawisata Bagi Lulusan Paket B (Pendidikan setara SMP) Kelas Berjalan Di Kelurahan Setiawargi Kecamatan Tamansari Kota Tasikmalaya. Pada dasarnya kegiatan ini bertujuan untuk memberikan kapasitas dan kemampuan untuk menciptakan kesadaran berwirawisata. Pelatihan Wirawisata Bagi Lulusan Paket B (Pendidikan setara SMP) Kelas Berjalan Di Kelurahan Setiawargi Kecamatan Tamansari Kota Tasikmalaya. Program pengabdian kepada masyarakat ini sebagai aplikasi dari Tri Dharma Perguruan Tinggi. Peran LP2M dan Dosen pelaksana Pengabdian Jurusan Pendidikan Luar Sekolah sebagai kontribusi nyata dan berusaha untuk menjembatani permasalahan yang terjadi di masyarakat. Pelatihan wirawisata dimaksudkan untuk menciptakan sumber daya manusia yang unggul dan berdaya saing sebagai bentuk pendampingan dan pelatihan wirawisata kepada masyarakat. Program pengabdian ini bermitra dengan PKBM GEMA dan Forum PKBM untuk pelaksanaan kegiatan. Pemilihan tema diharapkan representatif. Judul pada pengabdian ini adalah Pelatihan Wirawisata Bagi Lulusan Paket B Kelas Berjalan Di Kelurahan Setiawargi Kecamatan Tamansari Kota Tasikmalaya.
\end{abstract}

Kata Kunci : Pelatihan, Wirawisata, Pendidikan Kesetaraan

\begin{abstract}
Non-formal education is an education pathway that functions as a supplementary, supplementary and substitute for formal education. Non-formal education is very closely related in public education. Wirawisata Training For Graduates of the package B (National Junior High School Equivalency) Class Running in the Setiawargi Village, Tamansari District, Tasikmalaya City. Basically this activity aims to provide capacity and ability to create tourism awareness. Wirawisata Training For Graduates of the package B (National Junior High School Equivalency) Class Running in the Setiawargi Village, Tamansari District, Tasikmalaya City. This community service program is an application of the Higher Education Tri Dharma. The role of LP2M and the Lecturer implementing the Department of Education Outreach as a real contribution and trying to bridge the problems that occur in the community. Tourism training is intended to create superior and competitive human resources as a form of assistance and training in tourism to the community. This service program is partnering with the GEMA PKBM and the PKBM Forum for the implementation of activities. The theme selection is expected to be representative. The title of this dedication is Wirawisata Training for Graduates of the B Class Package Running in the Setiawargi Village, Tamansari District, Tasikmalaya City.
\end{abstract}

Keywords: Training, Wirawisata, Education Equality 


\section{PENDAHULUAN}

Pendidikan menurut Undang-undang No 20 Tahun 2003 tentang Sistem Pendidikan Nasional adalah usaha sadar dan terencana untuk mewujudkan suasana belajar dan proses pembelajaran agar peserta secara aktif mengembangkan potensi dirinya untuk memiliki kekuatan spiritual keagamaan, pengendalian diri, kepribadian, kecerdasan, akhlak mulia serta keterampilan yang diperlukan dirinya, masyarakat, bangsa dan Negara.

Pendidikan nonformal sebagai pendidikan yang berada di luar jalur pendidikan formal memiliki fungsi sebagai pengganti, penambah, dan/atau pelengkap pendidikan formal dalam rangka mendukung pendidikan sepanjang hayat. Pasal 26 ayat 3 pada Undang-undang SISDIKNAS dikatakan bahwa Satuan pendidikan nonformal terdiri atas lembaga kursus, lembaga pelatihan, kelompok belajar, pusat kegiatan belajar masyarakat, dan majelis taklim, serta satuan pendidikan yang sejenis. Pendidikan masyarakat maupun Pendidikan luar sekolah memiliki peran sebagai penambah, pengganti dan pelengkap Pendidikan formal. Pendidikan Luar Sekolah memiliki beberapa konsentrasi diantarannya Pendidikan kursus dan pelatihan, pemberdayaan masyarakat dan Pendidikan non formal dan informal (PNFI).

\section{KAJIAN TEORI}

\section{A. Kajian Pelatihan}

1. Pengertian Pelatihan

Pengertian menurut Bedjo Siswanto (2000:141) mengemukakan bahwa Pelatihan adalah manajemen pendidikan dan pelatihan secara menyeluruh mencakup fungsi yang terkandung di dalamnya, yakni perencanaan, pengaturan, pengendalian dan penilaian kegiatan umum maupun latihan keahlian, serta pendidikan dan latihan khusus bagi para pegawai pengaturannya meliputi kegiatan formulasi, kebutuhan pemberian servis yang memuaskan, bimbingan, perijinan dan penyelaan.

Lebih lanjut, Ambar Teguh Sulistiani dan Rosidah (2003:175), yang memberikan definisi mengenai Pelatihan adalah proses pendidikan jangka pendek dengan menggunakan prosedur sistematik pengubahan perilaku para pegawai dalam satu arah guna meningkatkan tujuan-tujuan organisasional. Pelatihan memiliki indikator keberhasilan dan kegiatan sebagai efektifitas pelatihan. Haywood (2001) menyatakan bahwa terdapat delapan hal yang mempengaruhi efektivitas pelatihan, yaitu berikut ini:

1) Dukungan organisasi atas perubahan;

2) Komitmen dan kepercayaan yang kuat dalam pendidikan, pelatihan dan pengembangan individu;

3) Pelatihan dan pengembangan harus berhubungan dengan strategi dan tujuan bisnis;

4) Formulasi dna implementasi dari strategi bisnis;

5) Peserta tidak hanya menerima pengetahuan dan kemampuan tetapi juga mendemonstrasikan kompetensi, termasuk untuk menemukan keinginan pelanggan;

6) Menyusun tujuan dan hasil yang diharapkan dari pelatihan;

7) Adanya spesifikasi dalam pelatihan; 
8) Evaluasi menyeluruh atas efektifitas pelatihan dan komitmen peserta selama proses pelatihan

\section{Pengertian Wirawisata}

Wirawisata berbeda dengan istilah wiraswasta. Wiraswasta merupakan kegiatan atau aktifitas yang memungkinkan adanya pekerjaan di sektor formal dan informal. Wirawisata dapat diartikan sebagai kegiatan berwisata dengan melaksanakan eksplorasi ke cagar alam maupun tempat wisata. Wirawisata dapat dalam bentuk kegiatan penelusuran gunung, goa ataupun kegiatan eksplorasi alam dalam aktifitas lain yang dikemas dalam kegiatan wisata.

Menurut Undang-undang No 25 Tahun 2000 tentang program Pembangunan Nasional, maka tujuan pembangunan pariwisata adalah :

1) Mengembangkan dan memperluas diversifikasi produk dan kualitas pariwisata nasional.

2) Berbasis pemberdayaan masyarakat, kesenian dan sumber daya (pesona) alam loka dengan memerhatikan kelestarian seni dan budaya tradisional serta kelestarian lingkungan hidup setempat.

3) Mengembangkan serta memperluas pasar pariwisata terutama pasar luar negri. Pada dasarnya pengembangan pariwisata adalah suatu proses yang berkesinambungan untuk melakukan matching dan adjusment yang terus menerus antara sisi supply dan demand kepariwisataan yang tersedia untuk mencapai misi yang telah ditentukan (Nuryanti, 1994).

\section{B. Permasalahan}

Berdasarkan observasi langsung ditemukan sebagai berikut:

1. Pendidikan Luar Sekolah memberikan pelatihan wirawisata dalam rangka mewujudkan pengembangan masyarakat yang sadar wisata dengan memanfaatkan potensi yang ada di kelurahan Setiawargi baik itu potensi sumber daya manusia maupun sumber daya alam yang ada di Kelurahan Setiawargi

2. Perlu dikembangkan pelatihan wirawisata yang sesuai dan tepat dengan masyarakat Kelurahan Setiawargi. Pelatihan berwirawisata diharapkan dapat memberikan manfaat secara luas dan membangun kompetensi warga belajar dalam membangun semangat untuk berwirawisata.

\section{METODOLOGI}

\section{A. Metode Pelaksanaan Kegiatan}

1. Tahap Persiapan

Sebelum melakukan pengabdian pada masyarakat melalui Pelatihan Wirawisata Bagi Lulusan Paket B Kelas Berjalan Di Kelurahan Setiawargi Kecamatan Tamansari Kota Tasikmalaya dimulai dengan melakukan observasi dimana selama ini belum dilakukan kegiatan pengabdian dengan Pelatihan Wirawisata Bagi Lulusan Paket B Kelas Berjalan Di Kelurahan Setiawargi Kecamatan Tamansari Kota Tasikmalaya. Peneliti juga melakukan kordinasi dengan warga belajar dalam rangka memberikan pelatihan ini. Agar hasil dari pelatihan dapat berjalan dengan optimal

2. Tahap Pelaksanaan Kegiatan 
Dalam upaya pelaksanaan pelatihan wirawisata bagi kelas berjalan program paket B di Kelurahan Setiawargi Tasikmalaya dilaksanakan melalui beberapa tahap:

a. Sosialisai

Sosialisasi program dilaksanakan setelah tahap persiapan selesai yaitu dengan melakukan pertemuan dengan calon peserta yang akan mengikuti pelatihan tentang program yang akan dilaksanakan.

b. Penyampaian Materi

Peserta diberikan materi tentang informasi. Penyampaian materi menggunakna media power point dan praktek langsung di tempat yang disediakan menggunakan aplikasi yang disediakan.

c. Penyusunan Laporan

Penyusunan laporan merupakan tahap akhit pelaksanaan program yaitu dengan menyusun dan membuat laporan hasil kegiatan pengabdian secara keseluruhan.

\section{B. Partisipasi Mitra dalam Pelaksanaan Kegiatan}

Partisipasi mitra dalam pelaksanaan pengabdian pada masyarakat melalui pelatihan dan pendampingan, yaitu kerjasama antara FK PKBM Kota Tasikmalaya dan PKBM Gema Kota Tasikmalaya dalam melaksanakan program kegiatan mengingat okasi pelaksanan kegiatan sangat menunjang berjalannya kegiatan. Kerjasama yang dilakukan dalam angka upaya membantu menyelesaikan permasalahan terkini yang dihadapi oleh pelaksana program, sehingga peran LP2M dan tim pelaksana pengabdian pada masyarakat menjadi jembatan untuk menyelesaikan permasalahan tersebut.

\section{HASIL DAN PEMBAHASAN}

1. Khalayak dan Jumlah Sasaran

Peserta pelatihan yang menjadi sasaran ekgaitan pelatihan wirawisata ini adalah warga belajar lulusan paket B berjalan dan Dosen Jurusan Pendidikan Masyarakat.

\section{Sarana dan Prasarana}

Sarana dan prasarana yang digunakan selama kegiatan pelatihan wirawisata yaitu LCD, Proyektor, Seminar Kit, dan Pemanfaatan ATK.

3. Jadwal Kegitan yang Disusun dengan Mitra

Kegaitan pelatihan ini dilaksanakan pada pukul 08.00 - 11.00 WIB dengan memanfaatkan ruang aula serbaguna keluruhan Setiawargi Kecamatan Tamansari Kota Tasikmalaya. Dalam pelatihan ini bekerjasama dengan lembaga mitra yakni FK PKBM Kota Tasikmalaya dan Keluruhan Setiawargi Kecamatan Tamansari Kota Tasikmalaya. 
Berdasarkan hasil pelaksanaan kegiatan pengabdian pada masyarakat dengan tema Pelatihan Wirawisata bagi kelas berjalan program paket B kelas berjalan di Kelurahan Setiawargi Kecamatan Tamansari Kota Tasikmalaya, para peserta didik perlu diberikanpemahaman tentang kesadaran dalam berwirawisata dan berwirausaha. Sehingga mereka dapat memiliki pengetahuan dan juga keahlian tentang wirawisata dan bagaimana membangun kapasitas diri sehingga memiliki pemahaman yang baik sebagai masyarakat yang sadar wisata.

Berdasarkan kegaitan pengabdian yang sudah dilaksanakan, terdapat beberapa hal yang menjadi saran atau rekomendasi baik untuk pengembangan keilmuan jurusan pendidikan masyarakat, pemangku kebijakan, warga belajar dan para praktisi pendidikan pelatihan semacam ini perlu dilaksanakan secara berkala dan teratur sehingga manfaatnya bisa dirasakan dalam rangka membangun pemahaman tentang wirawisata.

\section{DAFTAR PUSTAKA}

Ambar Teguh Sulistiyani. (2000). Manajemen dan Sumber Daya Manusia: Konsep Teori dan Pengembangan Dalam Konteks Organisasi Publik. Yogyakarta: Graha Ilmu.

Bedjo Siswanto (2000). Manajemen Tenaga kerja Indonesia Pendekatan Administratif dan Operasional. Jakarta: Bumi Aksara.

Haywood, K. Michael, (2001), "Effective Training: Toward a Strategic Approach", The Cornell H.R.A. Quarterly, December

Nuryanti, Wiendu, (1994). Perencanaan Pembangunan Regional dan Kawasan Untuk Kepariwisataan Alam, Makalah Disampaikan Pada Diklat Peningkatan Mutu Profesionalisme Pengelola Obyek dan Daya Tarik Pariwisata, Yogyakarta.

Santrock, J.W. (2004). Life-Span Development. Ninth Edition. Boston: McGraw-Hill Companies.

Undang-undang No 20 Tahun 2003 Tentang Sistem Pendidikan 